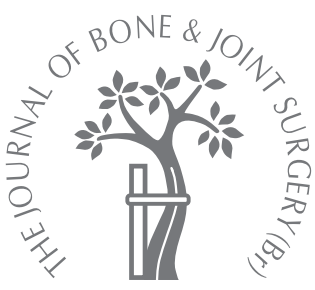

P. Herbertsson, R. Hasserius, P. O. Josefsson, J. Besjakov, F. Nyquist, A. Nordqvist, M. K. Karlsson

From Malmö University Hospital, Lund University, Malmö, Sweden

\title{
Mason type IV fractures of the elbow
}

\author{
A 14- TO 46-YEAR FOLLOW-UP STUDY
}

\begin{abstract}
A total of 14 women and seven men with a mean age of 43 years (18 to 68 ) who sustained a Mason type IV fracture of the elbow, without an additional type II or III coronoid fracture, were evaluated after a mean of 21 years (14 to 46). Primary treatment included closed elbow reduction followed by immobilisation in a plaster in all cases, with an additional excision of the radial head in 11, partial resection in two and suturing of the annular ligament in two.

Delayed radial head excision was performed in two patients and an ulnar nerve transposition in one. The uninjured elbows served as controls. Nine patients had no symptoms, 11 reported slight impairment, and one severe impairment of the elbow. Elbow flexion was impaired by a mean of $3^{\circ}$ (SD 4) and extension by a mean of $9^{\circ}$ (SD 4) (p< 0.01 ). None experienced chronic elbow instability or recurrent dislocation. There were more degenerative changes in the formerly injured elbows, but none had developed a reduction in joint space.

We conclude that most patients with a Mason type IV fracture of the elbow report a good long-term outcome.
\end{abstract}

A fall on the outstretched arm may result in a fracture of the radial head or neck. ${ }^{1}$ A similar fracture in conjunction with dislocation of the elbow is often referred to as a Mason type IV fracture. $^{2,3}$ Fractures of the radial head or neck are common, reported to occur in $17 \%$ to $19 \%$ of all elbow trauma, ${ }^{4,5}$ accounting for $25 \%$ to $33 \%$ of all fractures of the elbow ${ }^{3,6-11}$ and for $1.7 \%$ to $5.4 \%$ of all types of fracture. ${ }^{12,13}$ In contrast, Mason type IV fractures are rare. ${ }^{11}$ The injury is usually treated with open or closed reduction of the dislocation and excision of the radial head, ${ }^{3,14-17}$ or by open reduction and internal fixation ${ }^{16-22}$ of the radial head or with radial head replacement. ${ }^{22-27}$ Short-term studies report satisfactory outcomes following reduction of the dislocation with or without excision of the radial head. 2,28-31 However, other studies report unfavourable outcomes with this treatment strategy. ${ }^{28-32}$

These conclusions are based on the results of short-term investigations, small sample sizes and the inclusion of patients with additional elbow fractures, ${ }^{1-3,15,17,19,21}$ and there is a lack of data on the long-term outcome of Mason type IV fractures in the literature. The aim of this study, therefore, was to evaluate the long-term outcome of isolated Mason type IV fractures of the elbow.

\section{Patients and Methods}

In November 1970 our hospital served a city of 264937 inhabitants. The city has only one hospital with an emergency department and virtually all patients in the city with a fracture attend the emergency care clinic at the hospital. Previous studies have reported that less than $3 \%$ of all fracture patients in the city attend a private clinic, usually for fractures not requiring specific treatment. ${ }^{33}$ Furthermore, for the past century all the radiographs have been saved making it possible to re-evaluate and re-classify fractures. The radiographs of all elbow fractures between 1969 and 1979 were screened and a total of 2965 elbow fractures were identified, of which 756 (25\%) were fractures of the radial head or neck. Of these 480 were Mason type I (63\%), 222 were Mason type II (29\%), 36 were Mason type III (5\%), and 18 were Mason type IV (2\%) (Fig. 1a). Using the ten-digit personal identity number, specific for each citizen in our country, we could identify the former patients who were still alive and had not moved out of the region. Of the individuals with a Mason IV fracture, 11 were still living in the city at the time of the follow-up examination. All these patients participated in the study. However, as there were very few patients with a Mason type IV fracture without a coronoid fracture, we also 


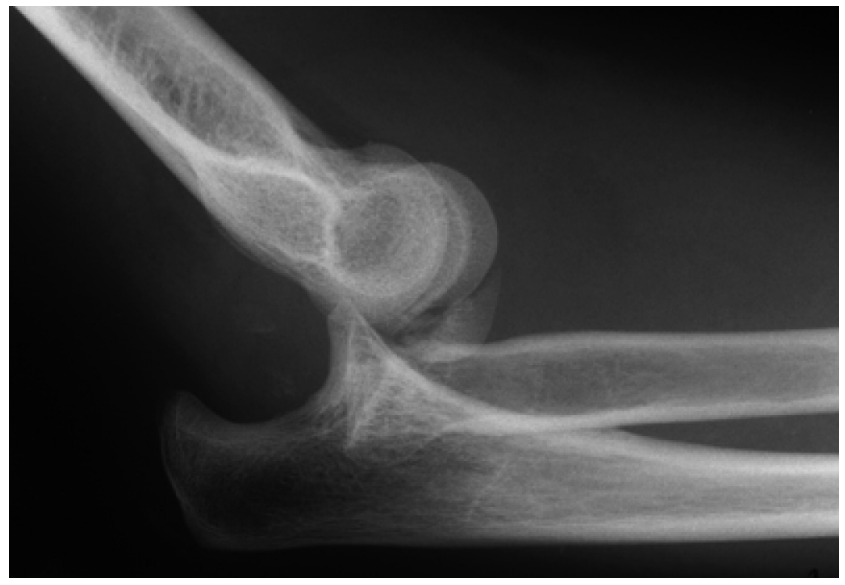

Fig. 1a

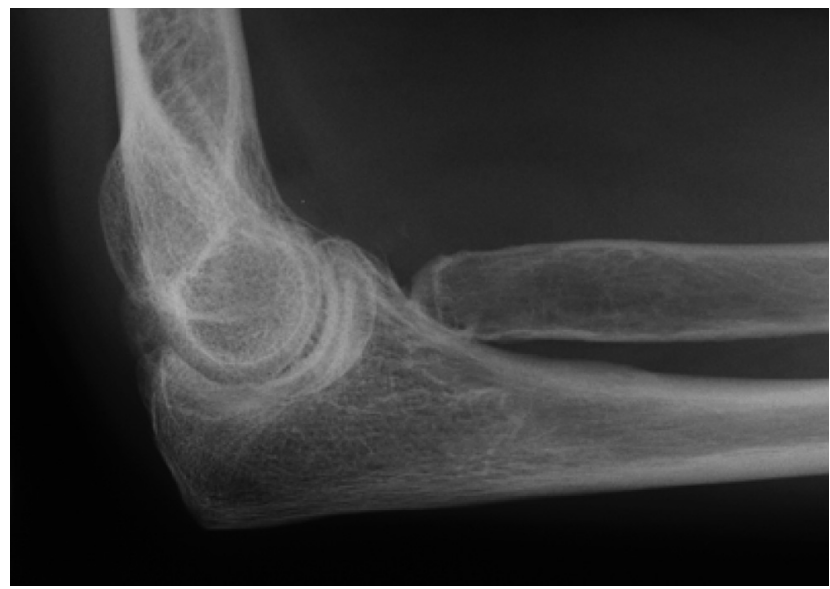

Fig. 1b

Lateral radiograph of the elbow showing a) a Mason type IV fracture initially treated by radial head excision, and b) at follow-up 21 years after the fracture.

scrutinised the in- and outpatient registers and the operation registers of the Department of Orthopaedics for patients treated for a Mason type IV fracture of the radial head or neck between 1957 and 1968, and between 1980 and 1989. This search identified another 42 individuals with this fracture type, of whom 21 were still living in the region at the time of follow-up. A total of 13 of these agreed to participate making a total of 24 . However, after examination three of the individuals with a former Mason type IV fracture were excluded, after examination, because they were found to have associated fractures in the same extremity, one in the distal radius, one in the capitellum and one in the olecranon. Of the 21 patients, 14 had a concomitant ligament injury at the initial injury. A total of 14 patients had a small avulsion of the coronoid process (Regan and Morrey type I injury), ${ }^{34}$ one had a minimal avulsion fragment of the lateral humeral condyle as a sign of a lateral ligament injury, and another had an avulsion fragment of the medial humeral condyle representing a medial ligament injury. Among the 21 patients with a dislocation of the elbow and an associated fracture of the radial head, the radial head injury was a Mason type I fracture in five individuals, a type II fracture in two and a type III fracture in 14.

There were 14 women and seven men, with a mean age of 43 years (18 to 68) at injury in the study group and the follow-up examination was conducted a mean of 21 years (14 to 46) after the injury. In nine patients the left elbow was affected and in 12 the right elbow. None had other major fractures or soft-tissue injuries to the upper extremities.

The type of injury and the primary and secondary treatments were retrospectively determined through the hospital records. A total of 16 patients had experienced low-energy trauma, defined as a fall in the same plane or a fall from less than $2 \mathrm{~m}$, or sustaining a kick or a blow, whereas five patients had suffered a high-energy trauma, defined as a fall from a height of more than $2 \mathrm{~m}$ or being involved in a motor-vehicle accident or a similar level of trauma. Primary treatment included closed reduction of the elbow dislocation and excision of the radial head in 11 patients, closed reduction of the dislocation and partial resection of the radial head in two, closed reduction of the dislocation and ligament suture in two, and closed reduction of the dislocation in six. All the patients were also treated with immobilisation in a plaster cast for a median of three weeks (2 to 6). The on-call surgeon decided on the treatment and we could not identify the specific reason for choosing a radial head excision as the primary form of treatment in any patient record. No intra- or post-operative complications were recorded. A delayed radial head excision was performed after one month in one patient and after three months in another because of residual pain. An ulnar nerve transposition was undertaken 18 months in one patient because of nerve compression symptoms.

The subjective outcome was recorded in all patients at follow-up by a questionnaire evaluating activities of daily living, elbow pain on loading and at rest, tenderness, loss of strength and range of movement in the previously fractured elbow. Pain in the ipsilateral wrist and hand were also evaluated.

Clinical examination was also performed in the 19 former patients who had accepted a radiological examination. Flexion and extension of the elbow and the wrist, pronation and supination of the forearm, and the angle of the extended elbow were measured with a goniometer. Grip strength of the hand was evaluated by a Martin vigorimeter (Heinrich C. Ulrich, Werkstätten für Medizinmechanik, Ulm-Donau, Germany) and the circumference of the arm and forearm respectively $10 \mathrm{~cm}$ above and below the tip of the olecranon was measured using a tape measure. The uninjured arm served as the control. The difference between the two sides in the strength of elbow flexion and extension was estimated by a subjective comparison between the elbows. Tinel's test in sulcus nervi ulnaris (cubital tunnel) was performed on both the elbows. 
The radiological evaluation at the time of injury included a plain anteroposterior (AP) and lateral radiograph of both the elbows. The fractures were classified according to the Mason classification ${ }^{3}$ modified by Broberg and Morrey $^{2}$ by a radiologist $(\mathrm{JB})$ with no knowledge of the treatment, subjective evaluation or clinical outcome. Follow-up radiographs were obtained in 19 patients and included an AP and lateral view of both elbows, and AP of the wrists. As the research protocol was unclear initially, the first five individuals who came for a follow-up examination had radiographs of their elbows only, and the wrist radiographs were obtained only for the 14 other patients. Degenerative changes were defined as subchondral cysts, sclerosis and/or osteophytes, and the number of patients with reduction of the joint space by more than $1 \mathrm{~mm}$ in comparison with the uninjured elbow was recorded. ${ }^{35}$ In the elbows where a radial head excision had been performed, joint space height was evaluated only in the medial compartment. Miscellaneous pathology, such as nonunion, avascular necrosis of the radial head, proximal radio-ulnar synostosis and periarticular ossification, were also evaluated. The prevalence of the length of the ulna exceeding that of the radius at the wrist by $2 \mathrm{~mm}$ or more when compared with the contralateral wrist was also recorded.

The study was approved by the Ethical Committee of Lund University and carried out according to the Declaration of Helsinki. ${ }^{36}$ Data are presented as median and range or mean and SD. Comparison between the two arms of the same individual was made by Student's $t$-test between pairs and the chi-squared or Fisher's exact test. A p-value of $<0.05$ was regarded as statistically significant.

\section{Results}

Of all the patients with a radial head or neck fracture during the period 1969 to 1979 , only $2 \%$ had a Mason type IV fracture. This implied an annual incidence of Mason type IV fractures of 0.06 per 10000 individuals $(0.006 \%)$ during this period. Furthermore, we found no patient below the age of 18 at the time of sustaining this fracture.

Subjectively, at follow-up nine of the 21 patients had no complaints in the formerly fractured elbow, 11 had slightly impaired elbow function, and one had severely impaired elbow function (Table I). The one with severe impairment was a woman who had suffered high-energy trauma and had been treated with closed reduction of the elbow dislocation followed by removal of the radial head. Four patients reported subjective reduction in grip strength in the formerly fractured arm. None had experienced recurrent dislocation of the elbow (Table I). Among the patients treated with excision of the radial head, four reported no elbow symptoms, whereas 11 reported a subjective impairment in the elbow. Of the two patients treated with a partial resection of the radial head, both reported an impairment in the elbow. Among the eight patients with non-operative treatment, five reported no elbow problems, whereas three reported elbow impairment. Among the five patients with a
Mason type I fracture of the radial head, three reported no symptoms but two reported subjective elbow impairment. One of the two patients with a Mason type II fracture reported no symptoms, and one reported some impairment. Finally, among the 14 patients with a Mason type III fracture, five reported no subjective elbow symptoms, whereas nine reported some impairment.

Objectively, the mean flexion of the elbow was impaired compared to the contralateal elbow $\left(140^{\circ}\right.$ (SD 8) versus $142^{\circ}$ (SD 7), $\left.\mathrm{p}<0.01\right)$, as was the mean extension $\left(-10^{\circ}\right.$ (SD 13) versus -1 (SD 2), $\mathrm{p}<0.01$ ) (Table II). Three individuals had an impaired extension of $20^{\circ}$ or more (Table I). None had flexion of less than $130^{\circ}$ in the formerly injured elbow. One patient had a positive Tinel's sign in the injured arm $(p=1.0)$. There was no objective reduction in grip strength or impaired range of movement in the wrists in the formerly fractured arm.

Radiologically, the formerly injured elbows had more degenerative changes than the uninjured elbows, cysts in ten $v s$ one, irregular subchondral bone in $14 v s$ one, and osteophytes in $11 v s$ two, $\mathrm{p}<0.01$ for all (Fig. 1). No formerly fractured elbows had a reduced joint space compared to the uninjured elbows. There were no nonunions, avascular necroses, proximal radio-ulnar synostoses and/ or periarticular ossifications. Apparent lengthening of the ulna of $2 \mathrm{~mm}$ or more was found in five formerly injured arms. None of these patients reported weakness of the wrist. The mean grip strength in the individuals with an ulna plus of more than $2 \mathrm{~mm}$ in the formerly injured arm was $0.75 \mathrm{~kg} / \mathrm{cm}^{2}$ (SD 0.23), compared to $0.80 \mathrm{kp} / \mathrm{cm}^{2}$ (SD 0.21) in the uninjured arm $(\mathrm{p}=0.19)$.

\section{Discussion}

This study supports the contention that Mason type IV fractures of the elbow are rare, practically not occurring in children, leaving no or only minor long-term symptoms in half of the cases up to 46 years after the trauma. However, it seems probable that we underestimated the actual number of such fractures. A Mason type IV fracture where the elbow dislocation was restored prior to the radiographs being obtained (and hence not captured on the radiographs) would, according to our classification system, not be a Mason type IV fracture. Only three of 21 patients had severe symptoms, and none had developed a radiological reduction in the joint space in the elbows. However, it is important to emphasise that patients with significant concomitant coronoid fractures, such as those seen in the terrible triad injuries (elbow dislocation, fracture of the radial head and fracture of the coronoid process), were excluded from this cohort and that the results in this report could not be generalised to patients with a significant coronoid fracture.

Mason $^{3}$ described a classification of radial head fractures including three different types of fracture. Dislocation of the elbow associated with a radial head fracture was first described as a Mason type IV by Johnston, ${ }^{37}$ and radial 
Table I. Case-specific information for the 21 individuals with a Mason type IV fracture

\begin{tabular}{|c|c|c|c|c|c|c|c|c|c|c|c|c|c|c|c|c|c|}
\hline \multirow[b]{2}{*}{ Case } & \multirow[b]{2}{*}{ Gender } & \multirow[b]{2}{*}{$\begin{array}{l}\text { Age at } \\
\text { injury } \\
\text { (yrs) }\end{array}$} & \multirow[b]{2}{*}{$\begin{array}{l}\text { Follow- } \\
\text { up (yrs) }\end{array}$} & \multirow[b]{2}{*}{$\begin{array}{l}\text { Trauma } \\
\text { type }\end{array}$} & \multirow[b]{2}{*}{ Injured side } & \multirow[b]{2}{*}{$\begin{array}{l}\text { Mason } \\
\text { type of } \\
\text { fracture }\end{array}$} & \multirow[b]{2}{*}{$\begin{array}{l}\text { Primary } \\
\text { treatment }\end{array}$} & \multirow[b]{2}{*}{$\begin{array}{l}\text { Plaster } \\
\text { (wks) }\end{array}$} & \multirow[b]{2}{*}{$\begin{array}{l}\text { Delayed } \\
\text { treatment }\end{array}$} & \multicolumn{4}{|c|}{ Subjective at follow-up } & \multicolumn{4}{|c|}{ Objective at follow-up } \\
\hline & & & & & & & & & & $\begin{array}{l}\text { Elbow } \\
\text { difference }\end{array}$ & Pain & $\begin{array}{l}\text { Range of } \\
\text { movement }\end{array}$ & Instability & $\begin{array}{l}\text { Flexion } \\
\text { deficit }\end{array}$ & $\begin{array}{l}\text { Extension } \\
\text { deficit }\end{array}$ & $\begin{array}{l}\text { Valgus } \\
\text { increase }\end{array}$ & $\begin{array}{l}\text { Mayo Elbow } \\
\text { Performance } \\
\text { score }\end{array}$ \\
\hline 1 & $\mathrm{~F}$ & 52 & 25 & $\begin{array}{l}\text { Low } \\
\text { energy }\end{array}$ & Dominant & IB & $\begin{array}{l}\text { Excision } \\
\text { radial head }\end{array}$ & 2.0 & & $\begin{array}{l}\text { No } \\
\text { difference }\end{array}$ & No & Normal & No & 0 & 5 & 10 & 80 \\
\hline 2 & $\mathrm{M}$ & 30 & 18 & $\begin{array}{l}\text { High } \\
\text { energy }\end{array}$ & Dominant & IIIA & $\begin{array}{l}\text { Excision } \\
\text { radial head }\end{array}$ & 2.0 & & $\begin{array}{l}\text { No } \\
\text { difference }\end{array}$ & No & Normal & No & 0 & 0 & 0 & 100 \\
\hline 3 & $\mathrm{~F}$ & 68 & 18 & $\begin{array}{l}\text { Low } \\
\text { energy }\end{array}$ & $\begin{array}{l}\text { non- } \\
\text { dominant }\end{array}$ & IIA & $\begin{array}{l}\text { Excision } \\
\text { radial head }\end{array}$ & 2.0 & & $\begin{array}{l}\text { No } \\
\text { difference }\end{array}$ & No & Normal & No & 5 & 0 & 0 & 100 \\
\hline 4 & $\mathrm{~F}$ & 55 & 22 & $\begin{array}{l}\text { Low } \\
\text { energy }\end{array}$ & Dominant & IIIA & $\begin{array}{l}\text { Excision } \\
\text { radial head }\end{array}$ & 3.0 & & $\begin{array}{l}\text { No } \\
\text { difference }\end{array}$ & No & Normal & No & - & - & & 100 \\
\hline 5 & $\mathrm{~F}$ & 49 & 16 & $\begin{array}{l}\text { Low } \\
\text { energy }\end{array}$ & $\begin{array}{l}\text { non- } \\
\text { dominant }\end{array}$ & IA & & 2.0 & & $\begin{array}{l}\text { No } \\
\text { difference }\end{array}$ & No & Normal & No & 0 & 10 & 0 & 100 \\
\hline 6 & $M$ & 42 & 14 & $\begin{array}{l}\text { Low } \\
\text { energy }\end{array}$ & $\begin{array}{l}\text { Non- } \\
\text { dominant }\end{array}$ & IA & & 2.5 & & $\begin{array}{l}\text { No } \\
\text { difference }\end{array}$ & No & Normal & No & 0 & 0 & 0 & 100 \\
\hline 7 & $\mathrm{~F}$ & 57 & 21 & $\begin{array}{l}\text { High } \\
\text { energy }\end{array}$ & Dominant & IIIA & & 4.0 & $\begin{array}{l}\text { Excision } \\
\text { radial } \\
\text { head }\end{array}$ & $\begin{array}{l}\text { No } \\
\text { difference }\end{array}$ & No & Normal & No & 0 & 0 & 0 & 100 \\
\hline 8 & $F$ & 53 & 22 & $\begin{array}{l}\text { Low } \\
\text { energy }\end{array}$ & $\begin{array}{l}\text { Non- } \\
\text { dominant }\end{array}$ & IIIA & & & & $\begin{array}{l}\text { No } \\
\text { difference }\end{array}$ & No & Normal & No & 0 & 0 & 0 & 100 \\
\hline 9 & $\mathrm{~F}$ & 48 & 15 & $\begin{array}{l}\text { Low } \\
\text { energy }\end{array}$ & Dominant & IIIA & $\begin{array}{l}\text { Suture } \\
\text { collateral } \\
\text { ligament }\end{array}$ & 6.0 & & $\begin{array}{l}\text { No } \\
\text { difference }\end{array}$ & No & Normal & No & - & - & & 100 \\
\hline 10 & $M$ & 22 & 46 & $\begin{array}{l}\text { Low } \\
\text { energy }\end{array}$ & Dominant & IIIA & $\begin{array}{l}\text { Excision } \\
\text { radial head }\end{array}$ & 2.0 & & $\begin{array}{l}\text { Slight } \\
\text { impairment }\end{array}$ & No & Reduced & No & 0 & 30 & 5 & 100 \\
\hline 11 & $\mathrm{~F}$ & 43 & 17 & $\begin{array}{l}\text { Low } \\
\text { energy }\end{array}$ & $\begin{array}{l}\text { Non- } \\
\text { dominant }\end{array}$ & IIIA & $\begin{array}{l}\text { Excision } \\
\text { radial head }\end{array}$ & 3.0 & $\begin{array}{l}\text { Transpo- } \\
\text { sition of } \\
\text { ulnar } \\
\text { nerve }\end{array}$ & $\begin{array}{l}\text { Slight } \\
\text { impairment }\end{array}$ & Yes & Reduced & Yes & 10 & 10 & 15 & 80 \\
\hline 12 & $M$ & 32 & 29 & $\begin{array}{l}\text { High } \\
\text { energy }\end{array}$ & Dominant & IIIA & $\begin{array}{l}\text { Excision } \\
\text { radial head }\end{array}$ & 2.0 & & $\begin{array}{l}\text { Slight } \\
\text { impairment }\end{array}$ & No & Reduced & No & 0 & 15 & 0 & 100 \\
\hline 13 & $\mathrm{~F}$ & 18 & 34 & $\begin{array}{l}\text { Low } \\
\text { energy }\end{array}$ & $\begin{array}{l}\text { Non- } \\
\text { dominant }\end{array}$ & IIIA & $\begin{array}{l}\text { Excision } \\
\text { radial head }\end{array}$ & 4.0 & & $\begin{array}{l}\text { Slight } \\
\text { impairment }\end{array}$ & No & Reduced & No & 5 & 10 & 5 & 100 \\
\hline 14 & $M$ & 31 & 22 & $\begin{array}{l}\text { High } \\
\text { energy }\end{array}$ & Dominant & IIIA & $\begin{array}{l}\text { Excision } \\
\text { radial head }\end{array}$ & 4.0 & & $\begin{array}{l}\text { Slight } \\
\text { impairment }\end{array}$ & No & Reduced & No & 0 & 0 & 10 & 100 \\
\hline 15 & $\mathrm{~F}$ & 52 & 15 & $\begin{array}{l}\text { Low } \\
\text { energy }\end{array}$ & Dominant & IIIA & $\begin{array}{l}\text { Excision } \\
\text { radial head }\end{array}$ & 4.0 & & $\begin{array}{l}\text { Slight } \\
\text { impairment }\end{array}$ & Yes & Normal & Yes & 0 & 0 & 10 & 100 \\
\hline 16 & $\mathrm{~F}$ & 60 & 17 & $\begin{array}{l}\text { Low } \\
\text { energy }\end{array}$ & Dominant & IIIA & & & & $\begin{array}{l}\text { Slight } \\
\text { impairment }\end{array}$ & No & Reduced & No & 0 & 20 & 0 & 100 \\
\hline 17 & $\mathrm{~F}$ & 50 & 15 & $\begin{array}{l}\text { Low } \\
\text { energy }\end{array}$ & Dominant & IIA & $\begin{array}{l}\text { Partial } \\
\text { resection } \\
\text { radial head }\end{array}$ & 2.0 & $\begin{array}{l}\text { Excision } \\
\text { radial } \\
\text { head }\end{array}$ & $\begin{array}{l}\text { Slight } \\
\text { impairment }\end{array}$ & Yes & Reduced & No & 10 & 0 & 5 & 85 \\
\hline 18 & $M$ & 45 & 14 & $\begin{array}{l}\text { Low } \\
\text { energy }\end{array}$ & Dominant & IIIA & $\begin{array}{l}\text { Partial } \\
\text { resection } \\
\text { radial head }\end{array}$ & 3.0 & & $\begin{array}{l}\text { Slight } \\
\text { impairment }\end{array}$ & No & Reduced & No & 5 & 55 & 0 & 95 \\
\hline 119 & $\mathrm{~F}$ & 26 & 20 & $\begin{array}{l}\text { Low } \\
\text { energy }\end{array}$ & Dominant & IA & & 5.0 & & $\begin{array}{l}\text { Slight } \\
\text { impairment }\end{array}$ & Yes & Reduced & No & 10 & 0 & -5 & 85 \\
\hline 20 & $M$ & 26 & 27 & $\begin{array}{l}\text { Low } \\
\text { energy }\end{array}$ & $\begin{array}{l}\text { Non- } \\
\text { dominant }\end{array}$ & IA & $\begin{array}{l}\text { Suture } \\
\text { collateral } \\
\text { ligament }\end{array}$ & 3.0 & & $\begin{array}{l}\text { Slight } \\
\text { impairment }\end{array}$ & No & Reduced & No & 5 & 10 & 5 & 100 \\
\hline 21 & $F$ & 34 & 15 & $\begin{array}{l}\text { High } \\
\text { energy }\end{array}$ & $\begin{array}{l}\text { Non- } \\
\text { dominant }\end{array}$ & IIIA & $\begin{array}{l}\text { Excision } \\
\text { radial head }\end{array}$ & 4.0 & & $\begin{array}{l}\text { Severe } \\
\text { impairment }\end{array}$ & No & Reduced & No & 0 & 10 & 0 & 100 \\
\hline
\end{tabular}

neck fractures were later included by Broberg and Morrey ${ }^{2}$ in their modified Mason classification. Mason type IV fractures are generally regarded as uncommon ${ }^{11}$ and only a few studies in the literature have followed those fractures over the longer term. Furthermore, most studies have been short-term follow-ups of a few individuals, including those with additional fractures of the elbow. $17,19,21,26,38-40$ Broberg and Morrey $^{2}$ followed 24 patients with a Mason type IV fracture for a mean of ten years, but they also included additional fractures of the coronoid process, the lateral epicondyle, the olecranon and the capitellum. The outcome in the 14 patients with a Mason type IV fracture without additional fractures was reported as excellent in two, good in seven (even if one had a re-dislocation two months after the injury) and fair in five. All the patients were treated by reduction of the dislocation and immobilisation in plaster, in two patients with an additional partial radial head resection, in two with a total radial head excision and in one with a radial head prosthesis. Esser, Davis and Taavao ${ }^{41}$ reported a good or excellent outcome in four of six patients with a Mason type IV fracture treated with reduction and internal fixation. However, in three patients there was also a fracture of the coronoid process, in two a fracture of the capitellum, and in one a fracture of the prox- 
Table II. Range of movement in elbows and wrists $\left({ }^{\circ}\right)$, circumference of upper arm and forearm $10 \mathrm{~cm}$ from the tip of the olecranon $(\mathrm{cm})$, and grip strength $\left(\mathrm{kp} / \mathrm{cm}^{2}\right)$ in the arms in 19 patients with an isolated Mason type IV fracture. Data are presented as mean (SD)

\begin{tabular}{lcc}
\hline & Formerly fractured arm & Non-fractured arm \\
\hline Elbow flexion $\left(^{\circ}\right)$ & $140(8)^{*}$ & $142(7)$ \\
Elbow extension $\left(^{\circ}\right)$ & $-10(13)^{*}$ & $-1(2)$ \\
Forearm pronation $\left(^{\circ}\right)$ & $80(16)$ & $84(8)$ \\
Forearm supination $\left(^{\circ}\right)$ & $74(12)$ & $76(11)$ \\
Elbow valgus angle $\left(^{\circ}\right)$ & $18(7)^{\dagger}$ & $15(6)$ \\
Wrist flexion $\left(^{\circ}\right)$ & $63(12)$ & $63(13)$ \\
Wrist extension $\left(^{\circ}\right)$ & $63(12)$ & $64(11)$ \\
Circumference upper arm in cm & $30(3)$ & $30(4)$ \\
Circumference forearm in cm & $27(4)$ & $27(4)$ \\
Grip strength $\left(\mathrm{kp} / \mathrm{cm}^{2}\right)$ & $0.6(0.3)$ & $0.6(0.2)$ \\
\hline
\end{tabular}

* $p<0.01$ comparing formerly fractured and non-fractured arms

$\dagger p<0.05$

imal humerus and bilateral fractures of the distal radius, making all the implications inconclusive. Also in the study by Josefsson et al, ${ }^{40}$ in which 19 patients with a Mason type IV fracture were followed up, 11 patients had additional elbow fractures. The outcome for the patients with an isolated Mason type IV fracture was not specifically reported. A study by Sanchez-Sotelo, Romanillos and Garay, ${ }^{42}$ following ten patients with a Mason type IV fracture for a mean of 4.6 years, reported excellent outcomes in four, good in five and fair in one. However, the authors concluded that pain was a problem in four patients, and that the long-term result could not be predicted by this study. There are also several studies that have included a Mason type IV fracture in the evaluation of Mason type II, III and IV fractures without specifically reporting the outcome of the Mason type IV fractures. ${ }^{17,19,21,26,38,39}$ As a majority of the patients in these studies had sustained a Mason type II or III fracture, no conclusions could be drawn with regard to the outcome of a Mason type IV fracture.

Another interesting observation in the study by Josefsson et $\mathrm{al},{ }^{35}$ as in the present report, is that all individuals with a Mason type IV fracture with or without a small avulsion fragment of the coronoid process did not have recurrent elbow dislocations. ${ }^{34}$ Similar conclusions have been made by other authors ${ }^{43}$ but opposed by others. ${ }^{14,27,32,43-45} \mathrm{~A}$ common recommendation in the literature is that excision of the radial head should be performed two to three weeks after the injury to reduce the risk of instability. ${ }^{14}$ However, even if the radial head excisions were performed in conjunction with the injury in this cohort, there were no recurrent elbow dislocations. Thus, isolated Mason type IV fractures do not seem in general to be complicated by recurrent dislocation of the elbows.

Several authors imply that subjective symptoms occur with an elbow extension deficit exceeding $30^{\circ}$ and/or if the elbow flexion falls short of $130^{\circ} .^{31,46-49}$ We report a significantly impaired elbow extension and flexion in the formerly injured elbows, with the residual deficit having a magnitude of no biological significance. It is apparent that a statistically significant difference is not the same as a biologically significant difference, as most former patients rated their injured elbow as having no or only minor discomfort.

This study suggests that radiological deformities occur in a large proportion of former patients with a Mason type IV fracture, although the risk of developing a reduced joint space does not seem to be increased. These findings support previous reports, which indicate that degenerative changes are found in a majority of cases with a previous elbow fracture, but that the risk of developing a reduced joint space is small. ${ }^{9-11,48,50}$ In addition, there was no apparent correlation between the prevalence of degenerative changes that occurred in the majority of the patients and the prevalence of severe symptoms that occurred in a minority of cases. This is similar to reports following Mason type II and III fractures. ${ }^{6-11}$ Also, the risk of developing relative lengthening of the ulna, commonly referred to as an ulna plus arm with wrist problems in the formerly injured arm seemed to be low after a Mason type IV fracture, even in patients in whom a radial excision had been performed.

The main strength of this study is that it is the first published study to include only patients with an isolated Mason type IV fracture and it includes the largest sample of patients with this injury with the longest follow-up presented, including a radiological follow-up of both elbows and wrists. The weakness is that no randomised treatment was advocated. However, a randomised study with up to 46 years' follow-up is unlikely to ever succeed. Furthermore, because of the sample size, this study cannot verify or reject the hypothesis that individuals whose radial head was preserved had a more favourable outcome than those whose radial head was excised. Also, the study could not address the hypothesis that patients who undergo internal fixation of the radial head or a replacement by a radial head prosthesis have a more favourable outcome, ${ }^{14,15,17,19,21,23,26,38,39,44,45,51,52}$ as this treatment strategy was not advocated at the time when the patients in this study were treated.

In summary, even if Mason type IV fractures of the elbow are usually regarded as serious, no more than three of the 
21 patients reported severe long-term symtoms. Whether preservation of the radial head or replacement with aprosthesis leads to a more favourable outcome cannot be determined by this study.

\section{Supplementary material}

$\ddot{e}$ A further opinion by Mr D. Limb is available with the electronic version of this article on our website at www.jbjs.org.uk

Financial support was provided by the Region Skåne, the Malmö and Lund Universities Foundations, the Pahlsson and the Herman Jarnhardt Foundations.

No benefits in any form have been received or will be received from a commercial party related directly or indirectly to the subject of this article.

\section{References}

1. Odelberg-Johnsson G. Fractures of the proximal portion of the radius and their causes. Acta Radiol 1924;3:45-53

2. Broberg MA, Morrey BF. Results of treatment of fracture-dislocations of the elbow. Clin Orthop 1987;216:109-19.

3. Mason ML. Some observations on fractures of the head of the radius with a review of one hundred cases. Br J Surg 1954;42:123-32.

4. Watson-Jones R. Fractures and other bone and joint injuries. Second ed. Baltimore, The Williams \& Wilkins Co, 1941:336.

5. Wilson PD. Fracture and dislocation in the region of the elbow. Surg Gynecol Obstet 1933;56:335.

6. Malmvik J, Herbertsson $\mathbf{P}$, Josefsson PO, et al. Fracture of the radial head and neck of Mason types II and III during growth: a 14-25 year follow-up. J Pediatr Orthop B 2003;12:63-8.

7. Akesson T, Herbertsson P, Josefsson P0, et al. Primary nonoperative treatment of moderately displaced two-part fractures of the radial head. J Bone Joint Surg [Am] 2006;88-A:1909-14.

8. Akesson T, Herbertsson P, Josefsson PO, et al. Displaced fractures of the neck of the radius in adults: an excellent long-term outcome. J Bone Joint Surg [Br] 2006;88B:642-4.

9. Herbertsson P, Josefsson PO, Hasserius R, et al. Uncomplicated Mason type II and III fractures of the radial head and neck in adults. J Bone Joint Surg [Am]2004;86-A:569-74.

10. Herbertsson P, Josefsson PO, Hasserius $\mathbf{R}$, et al. Fractures of the radial head and neck treated with radial head excision. J Bone Joint Surg [Am] 2004;86-A:1925-30.

11. Herbertsson P. Radial head and neck fractures. Department of Orthopaedics. Malmö: Lund University, 2004

12. Conn J, Wade P. Injuries of the elbow: a ten year review. J Trauma 1961;1:248-68

13. Murray R. Fractures of the head and neck of the radius. Br J Surg 1939;28:106-18.

14. Ring D, Jupiter JB, Zilberfarb J. Posterior dislocations of the elbow with fractures of the radial head and coronoid. J Bone Joint Surg [Am] 2002;84-A:547-51.

15. Pugh DM, Wild LM, Schemitsch EH, King GJ, McKee MD. Standard surgical protocol to treat elbow dislocations with radial head and coronoid fractures. J Bone Joint Surg [Am] 2004;86-A:1122-30.

16. Ikeda M, Sugiyama K, Kang C, Takagaki T, Oka Y. Comminuted fractures of the radial head: comparison of resection and internal fixation. J Bone Joint Surg [Am] 2005;87-A:76-84.

17. Struijs PA, Smit G, Steller EP. Radial head fractures: effectiveness of conservative treatment versus surgical intervention: a systematic review. Arch Orthop Trauma Surg 2007;127:125-30.

18. Ring D, Quintero J, Jupiter JB. Open reduction and internal fixation of fractures of the radial head. J Bone Joint Surg [Am] 2002;84-A:1811-15.

19. Givissis PK, Symeonidis PD, Ditsios KT, Dionellis PS, Christodoulou AG. Late results of absorbable pin fixation in the treatment of radial head fractures. Clin Orthop 2008;466:1217-24

20. Ikeda M, Yamashina Y, Kamimoto M, Oka Y. Open reduction and internal fixation of comminuted fractures of the radial head using low-profile mini-plates. J Bone Joint Surg [Br] 2003;85-B:1040-4

21. Nalbantoglu U, Kocaoglu B, Gereli A, Aktas S, Guven 0. Open reduction and internal fixation of Mason type III radial head fractures with and without an associated elbow dislocation. J Hand Surg [Am] 2007;32:1560-8.

22. Ruan HJ, Fan CY, Liu JJ, Zeng BF. A comparative study of internal fixation and prosthesis replacement for radial head fractures of Mason type III. Int Orthop 2009:33:249-53.
23. Ring D, King G. Radial head arthroplasty with a modular metal spacer to treat acute traumatic elbow instability: surgical technique. J Bone Joint Surg [Am] 2008;90 A(Suppl 2 Pt 1):63-73.

24. Hou ZH, Zhou JH, Shi JG, et al. Treatment of displaced radial head fractures by internal fixation with absorbable pins. Chin J Traumato/ 2006;9:356-8.

25. Ashwood N, Bain GI, Unni R. Management of Mason type-III radial head fractures with a titanium prosthesis, ligament repair, and early mobilization. J Bone Joint Surg [Am] 2004;86-A:274-80.

26. Grewal R, MacDermid JC, Faber KJ, Drosdowech DS, King GJ. Comminuted radial head fractures treated with a modular metallic radial head arthroplasty: study of outcomes. J Bone Joint Surg [Am] 2006;88-A:2192-200.

27. Dotzis A, Cochu G, Mabit C, Charissoux JL, Arnaud JP. Comminuted fractures of the radial head treated by the Judet floating radial head prosthesis. J Bone Joint Surg [Br] 2006;88-B:760-4.

28. Ikeda M, Oka Y. Function after early radial head resection for fracture: a retrospective evaluation of 15 patients followed for 3-18 years. Acta Orthop Scand 2000;71:191-4

29. Poulsen J0, Tophoj K. Fracture of the head and neck of the radius: follow-up on 61 patients. Acta Orthop Scand 1974;45:66-75

30. Bakalim G. Fractures of radial head and their treatment. Acta Orthop Scand 1970;41:320-31

31. Stephen IB. Excision of the radial head for closed fracture. Acta Orthop Scand 1981;52:409-12.

32. Helferich H. Fractures and dislocations. Translated by J. Hutchinson. New Sydenheim Society 1899:96-7.

33. Jonsson B, Gardsell P, Johnell O, Redlund-Johnell I, Sernbo I. Remembering fractures: fracture registeration and proband recall in southern Sweden. J Epidemio Community Health 1994;48:489-90.

34. Regan W, Morrey B. Fractures of the coronoid process of the ulna. J Bone Joint Surg [Am] 1989;71-A:1348-54.

35. Josefsson PO, Johnell 0, Gentz CF. Long-term sequelae of simple dislocation of the elbow. J Bone Joint Surg [Am] 1984;66-A:927-30.

36. World Medical Association Declaration of Helsinki. Ethical principles for med ical research involving human rights subjects. Bull Med Eth 2000;162:162:8-11.

37. Johnston GW. A follow-up of one hundred cases of fracture of the head of the radius with a review of the literature. Ulster Med J 1962;31:51-6.

38. Ozturk K, Esenyel CZ, Orhun E, Ortak O, Durmaz H. The results of open reduction and internal fixation of radial head fractures. Acta Orthop Traumatol Turc 2004;38:42 9 (in Turkish).

39. Moro JK, MacDermid JC, Patterson SD, King GJ. Arthroplasty with metal radial head for unreconstructible fractures of the radial head. J Bone Joint Surg [Am] 2001;83-A:1201-11

40. Josefsson P, Gentz CF, Johnell $\mathbf{0}$, Wendeberg B. Dislocations of the elbow and intraarticular fractures. Clin Orthop 1989;246:126-30.

41. Esser RD, Davis $\mathbf{S}$, Taavao T. Fractures of the radial head treated by internal fixation: late results in 26 cases. J Orthop Trauma 1995;9:318-23.

42. Sanchez-Sotelo J, Romanillos O, Garay EG. Results of acute excision of the radial head in elbow radial head fracture-dislocations. J Orthop Trauma 2000;14:354-8.

43. Forthman C, Henket M, Ring DC. Elbow dislocation with intra-articular fracture: the results of operative treatment without repair of the medial collateral ligament. $J$ Hand Surg [Am] 2007;32:1200-9.

44. Kalicke T, Muhr G, Frangen TM. Dislocation of the elbow with fractures of the coronoid process and radial head. Arch Orthop Trauma Surg 2007;127:925-31.

45. Lindenhovius AL, Jupiter JB, Ring D. Comparison of acute versus subacute treatment of terrible triad injuries of the elbow. J Hand Surg [Am] 2008;33:920-6.

46. Coleman DA, Blair WF, Shurr D. Resection of the radial head for fracture of the radial head: long-term follow-up of seventeen cases. J Bone Joint Surg [Am]1987;69A:385-92.

47. Goldberg I, Peylan J, Yosipovitsch Z. Late results of excision of the radial head for an isolated closed fracture. J Bone Joint Surg [Am] 1986;68-A:675-9.

48. Morrey BF, Askews LJ, Chao EY. A biomechanical study of normal functional elbow motion. J Bone Joint Surg [Am] 1981;63-A:872-7.

49. Morrey BF, Chao EY, Hui FC. A biomechanical study of the elbow following excision of the radial head. J Bone Joint Surg [Am] 1979;61-A:63-8.

50. Mikic ZD, Vukadinovic SM. Late results in fractures of the radial head treated by excision. Clin Orthop 1983;181:220-8.

51. Ikeda M, Sugiyama K, Kang C, Takagaki T, Oka Y. Comminuted fractures of the radial head: comparison of resection and internal fixation: surgical technique. J Bone Joint Surg [Am] 2006;88-A(Suppl 1 Pt 1):11-23.

52. McKee MD, Pugh DM, Wild LM, Schemitsch EH, King GJ. Standard surgica protocol to treat elbow dislocations with radial head and coronoid fractures: surgical technique. J Bone Joint Surg [Am] 2005;87-A(Suppl 1 Pt 1):22-32. 